\title{
FAKTOR-FAKTOR YANG MEMPENGARUHI PERILAKU TENAGA KERJA DALAM PENGGUNAAN ALAT PELINDUNG DIRI DI PROYEK KONSTRUKSI
}

\author{
Veronika Happy Puspasari, Wita Kristiana, dan Aji Saputra \\ Jurusan/Program Studi Teknik Sipil, Fakultas Teknik, Universitas Palangka Raya \\ Jln. Hendrik Timang, Palangka Raya \\ E-mail: vhappy_75@yahoo.com
}

\begin{abstract}
Abstrak: Pembangunan proyek kontruksi umumnya merupakan kegiatan yang banyak mengandung unsur bahaya. Kecelakaan kerja dapat terjadi disebabkan oleh faktor lingkungan dan manusia. Faktor lingkungan terkait dengan peralatan, kebijakan, pengawasan, peraturan, dan prosedur kerja mengenai pelaksanaan keselamatan dan kesehatan kerja.Sedangkan faktor manusia yaitu perilaku atau kebiasaan kerja yang tidak aman. Berdasarkan studi pendahuluan yang dilaksanakan bulan April 2017 pada Kegiatan Pembangunan Fisik Gedung dan Bangunan Rumah Sakit Umum Daerah Kota Palangka Raya Tahap II, diketahui terdapat 36 tenaga kerja dan kebanyakan dari tenaga kerja tersebut tidak menggunakan alat pelindung diri saat mereka sedang bekerja. Hal ini mencerminkan buruknya perilaku dan masih kurangnya tingkat kesadaran tenaga kerja dalam penggunaan alat diri. Penelitian ini bertujuan mengetahui faktor-faktor yang mempengaruhi perilaku tenaga kerja dalam penggunaan alat pelindung diri di proyek konstruksi. Faktor predisposisi meliputi pengetahuan, sikap dan kenyamanan. Faktor pemungkin meliputi ketersediaan fasilitas dan pelatihan. Faktor penguat meliputi pengawasan, hukuman, penghargaan, motivasi dan komunikasi. Sedangkan faktor individu meliputi pendidikan, umur dan masa kerja. Teknik pemilihan sampel adalah non random sampling dan sebanyak 33 sampel yang dipilih berdasarkan kriteria yang sudah ditentukan. Teknik analisis data yang digunakan adalah analisis deskriptif. Hasil analisis deskriptif menunjukan bahwa faktor-faktor yang mempengaruhi perilaku tenaga kerja dalam penggunaan alat pelindung diri di proyek konstruksi adalah faktor predisposisi, faktor pemungkin, faktor penguat, dan faktor individu. Faktor dominan yang mempengaruhi perilaku tenaga kerja dalam penggunaan alat pelindung diri di proyek konstruksi adalah faktor predisposisi dengan nilai mean 4,35, faktor pemungkin dengan nilai mean 4,29, faktor penguat dengan nilai mean 4,19 dan faktor individu dengan nilai mean 3,73 .
\end{abstract}

Kata kunci: : Perilaku, alat pelindung diri, proyek konstruksi, analisis deskriptif.

\section{PENDAHULUAN}

Bidang konstruksi mempunyai karakteristik yang sangat spesifik dan unik. Dimana setiap proyek menghadirkan persoalan yang berbeda pada setiap proses pengerjaannya. Proses yang terjadi pada suatu proyek tidak akan berulang pada proyek lainnya. Hal ini disebabkan oleh kondisi yang mempengaruhi proses suatu proyek konstruksi berbeda satu sama lain.

Pembangunan proyek kontruksi pada umumnya merupakan kegiatan yang banyak mengandung unsur bahaya. Situasi dalam lokasi proyek mencerminkan karakter yang keras serta kegiatannya terlihat sangat kompleks dan dinamis dilaksanakan sehingga dibutuhkan kondisi yang prima dari tenaga kerja yang melaksanakannya. Karakteristik-karakteristik ini yang menyebabkan kondisi proyek konstruksi berbahaya dan rawan terjadi kecelakaan kerja (Ervianto, 2005).

Indonesia merupakan salah satu dari negara yang sedang berkembang. Ancaman kecelakaan di tempat kerja di negara berkembang seperti Indonesia masih sangat tinggi. Hal itu terjadi karena belum adanya pengetahuan yang baik dari pengusaha atau penyedia jasa dan para tenaga kerja (Gerard Hand, 2013). King dan Hudson (1985) menyatakan bahwa proyek konstruksi di negara-negara berkembang, terdapat tiga kali lipat tingkat kematian dibandingkan dengan di negara-negara maju. Kecelakaan kerja dapat terjadi karena disebabkan beberapa faktor antara lain adanya faktor lingkungan dan manusia. Faktor lingkungan terkait dengan peralatan, kebijakan, pengawasan, peraturan, dan prosedur kerja 
mengenai pelaksanaan keselamatan dan kesehatan kerja. Sedangkan faktor manusia yaitu perilaku atau kebiasaan kerja yang tidak aman (Suma' mur, 2010).

Studi pendahuluan yang dilaksanakan bulan April 2017 pada Kegiatan Pembangunan Fisik Gedung dan Bangunan Rumah Sakit Umum Daerah (RSUD) Kota Palangka Raya Tahap II yang berada di Jalan Mahir Mahar Km. 18,5, Kecamatan Sabangau, Kota Palangka Raya memberikan informasi bahwa terdapat 36 tenaga kerja (mandor atau kepala tukang, tukang dan buruh bangunan atau laden tukang) yang bekerja pada proyek tersebut dan kebanyakan dari tenaga kerja tersebut tidak menggunakan alat pelindung diri saat mereka sedang bekerja. Mengingat proyek konstruksi pada umumnya banyak mengandung unsur bahaya, perilaku ini dapat menimbulkan kecelakaan kerja yang bisa membahayakan para tenaga kerja tersebut. Hal ini juga mencerminkan buruknya perilaku dan masih kurangnya tingkat kesadaran tenaga kerja dalam penggunaan alat pelindung diri.

Berdasarkan latar belakang tersebut dan belum adanya penelitian mengenai faktor-faktor yang mempengaruhi perilaku tenaga kerja dalam penggunaan alat pelindung diri di proyek konstruksi, sehingga perlu dilakukan penelitian mengenai faktor-faktor yang mempengaruhi perilaku tenaga kerja dalam penggunaan alat pelindung diri di proyek konstruksi pada Kegiatan Pembangunan Fisik Gedung dan Bangunan Rumah Sakit Umum Daerah (RSUD) Kota Palangka Raya Tahap II.

Berdasarkan uraian di atas maka rumusan masalah penelitian ini adalah apa faktor-faktor yang mempengaruhi perilaku tenaga kerja dalam penggunaan alat pelindung diri di proyek konstruksi pada kegiatan pembangunan fisik gedung dan bangunan Rumah Sakit Umum Daerah (RSUD) Kota Palangka Raya Tahap II, apa faktor dominan yang mempengaruhi perilaku tenaga kerja dalam penggunaan alat pelindung diri di proyek konstruksi pada kegiatan Pembangunan Fisik Gedung dan Bangunan Rumah Sakit Umum Daerah (RSUD) Kota Palangka Raya Tahap II.

Batasan masalah penelitian ini adalah faktorfaktor yang mempengaruhi perilaku tenaga kerja dalam penggunaan alat pelindung diri di proyek konstruksi pada kegiatan Pembangunan Fisik Gedung dan Bangunan Rumah Sakit Umum Daerah (RSUD) Kota Palangka Raya Tahap II. Penelitian ini dilakukan pada Kegiatan Pembangunan Fisik Gedung dan Bangunan Rumah Sakit Umum Daerah (RSUD) Kota Palangka Raya Tahap II yang berada di Jalan Mahir Mahar Km. 18,5, Kecamatan Sabangau, Kota Palangka Raya. Responden adalah tenaga kerja konstruksi yang telah memenuhi kriteria-kriteria yang sudah ditentukan.

Tujuan penelitian ini adalah untuk mengetahui faktor-faktor yang mempengaruhi perilaku tenaga kerja dalam penggunaan alat pelindung diri di proyek konstruksi pada kegiatan Pembangunan Fisik Gedung dan Bangunan Rumah Sakit Umum Daerah (RSUD) Kota Palangka Raya Tahap II dan untuk mengetahui faktor dominan yang mempengaruhi perilaku tenaga kerja dalam penggunaan alat pelindung diri di proyek konstruksi pada kegiatan Pembangunan Fisik Gedung dan Bangunan Rumah Sakit Umum Daerah (RSUD) Kota Palangka Raya Tahap II.

Manfaat penelitian ini adalah memberikan tambahan pengetahuan dan informasi serta wawasan mengenai faktor-faktor yang mempengaruhi perilaku tenaga kerja dalam penggunaan alat pelindung diri di proyek konstruksi, memberikan pemahaman kepada para tenaga kerja konstruksi mengenai faktorfaktor yang mempengaruhi perilaku tenaga kerja dalam penggunaan alat pelindung diri di proyek konstruksi dan akan pentingnya penggunaan alat pelindung diri disaat mereka sedang bekerja, menjadi dasar pertimbangan dalam menjalankan program keselamatan dan kesehatan kerja. Sehingga dengan demikian dapat diwujudkan proyek dengan kecelakaan kerja seminimal mungkin.

\section{TINJAUAN PUSTAKA}

\section{Keselamatan dan Kesehatan Kerja}

Menurut Suma'mur (1995) keselamatan dan kesehatan kerja (K3) adalah sarana utama untuk mencegah terjadinya kecelakaan, cacat, dan kematian akibat kecelakaan kerja. Keselamatan kerja yang baik adalah pintu gerbang bagi keamanan tenaga kerja. Kecelakaan kerja dapat 
menimbulkan kerugian secara tidak langsung, seperti kerusakan mesin dan peralatan kerja, terhentinya proses produksi untuk beberapa saat, serta kerusakan pada lingkungan kerja.

\section{Alat Pelindung Diri}

Secara sederhana Alat Pelindung Diri (APD) adalah seperangkat alat yang digunakan tenaga kerja untuk melindungi sebagian atau seluruh tubuhnya dari adanya bahaya atau kecelakaan kerja. Jenis Alat pelindung diri banyak macamnya menurut bagian tubuh yang dilindunginya (Suma'mur, 1996).

\section{Proyek Konstruksi}

Menurut Ervianto (2005), suatu proyek konstruksi merupakan suatu rangkaian kegiatan yang hanya satu kali dilaksanakan dan umumnya berjangka waktu pendek. Selain itu, proyek konstruksi juga memiliki karakteristik yaitu bersifat unik, membutuhkan sumber daya (manpower, material, machines, money, method), serta membutuhkan organisasi.

\section{Teori Perilaku Kerja}

Menurut Notoadmodjo (2003), menyimpulkan teori Lawrence Green yaitu perilaku manusia dibentuk oleh 3 faktor, yaitu faktor predisposisi, faktor pemungkin dan faktor penguat.

a. Faktor Predisposisi (Predisposing Factors)

Faktor predisposisi (predisposing factors) yaitu faktor yang mempermudah terjadinya perilaku seseorang. Misalnya: Pengetahuan, sikap dan kenyamanan.

b. Faktor Pemungkin (Enabling Factors)

Faktor pemungkin (enabling factors) adalah faktor yang memungkinkan atau memfasilitasi perilaku antara lain sarana dan prasarana. Misalnya: Ketersediaan fasilitas dan pelatihan.

c. Faktor Penguat (Reinforcement Factors)

Faktor penguat (reinforcement factors) merupakan faktor yang mendorong atau memperkuat terjadinya perilaku. Misalnya: Pengawasan, hukuman, penghargaan, motivasi dan komunikasi.

Teori Sosial Kognitif (Social Cognitive Theory) merupakan teori perilaku kesehatan yang dikembangkan oleh Albert Bandura tahun 1963. Teori sosial kognitif terdapat 3 (tiga) faktor yang mempengaruhi perilaku seseorang yaitu orang, perilaku, dan lingkungan, dimana satu sama lain saling berhubungan. Menurut teori ini, individu secara unik ditentukan oleh masing-masing tiga faktor, yaitu:

a. Faktor Individu

Faktor orang (individu) yaitu faktor yang berasal dari orang/individu itu sendiri. Misalnya: Pendidikan, umur dan masa kerja.

b. Perilaku

Pada teori sosial kognitif, perilaku bersifat dinamis. Tergantung pada aspek lingkungan dan individu dimana semuanya saling mempengaruhi satu sama lain. Interaksi ini berlanjut antara karakteristik individu, perilaku dan lingkungan dimana perilaku ditunjukkan yang disebut pengaruh timbal balik (reciprocal determinism). Misalnya: Kepatuhan dan penerapan.

c. Lingkungan

Faktor lingkungan yaitu faktor yang berasal dari sekitar individu faktor yang dapat mempengaruhi perilaku seseorang tetapi merupakan faktor eksternal. Misalnya: Ketersediaan fasilitas yang disediakan, hukuman dan pengawasan.

\section{Faktor yang Mempengaruhi Perilaku Kerja}

Beberapa faktor yang mempengaruhi perilaku kerja: Notoadmodjo (2003) dan (Bandura, 1963)

1. Faktor predisposisi (predisposing factors) yaitu faktor yang mempermudah terjadinya perilaku seseorang. Misalnya: Pengetahuan, sikap dan kenyamanan.

2. Faktor pemungkin (enabling factors) adalah faktor yang memungkinkan atau memfasilitasi perilaku antara lain sarana dan prasarana. Misalnya: Ketersediaan fasilitas dan pelatihan.

3. Faktor penguat (reinforcement factors) merupakan faktor yang mendorong atau memperkuat terjadinya perilaku. Misalnya: Pengawasan, hukuman, penghargaan, motivasi dan komunikasi.

4. Faktor orang (individu) yaitu faktor yang berasal dari orang/individu itu sendiri. Misalnya: Pendidikan, umur dan masa kerja.

\section{METODE PENELITIAN Pendekatan Penelitian}

Menurut Sugiyono (2010), pendekatan penelitian dapat diartikan sebagai cara ilmiah untuk mendapatkan data yang valid dengan 
tujuan dapat di temukan, dibuktikan dan dikembangkan suatu pengetahuan sehingga pada gilirannya dapat digunakan untuk memahami, memecahkan dan mengantisipasi masalah yang ada. Pendekatan penelitian adalah pendekatan deskriptif kuantitatif.

\section{Waktu dan Lokasi Penelitian}

Waktu penelitian dilakukan pada bulan April 2017 dan lokasi penelitian pada Kegiatan Pembangunan Fisik Gedung dan Bangunan Rumah Sakit Umum Daerah (RSUD) Kota Palangka Raya Tahap II yang berada di Jalan Mahir Mahar Km. 18,5 Kecamatan Sabangau, Kota Palangka Raya, Provinsi Kalimantan Tengah.

\section{Teknik Pengumpulan Data}

Teknik pengumpulan data merupakan langkah yang paling strategis dalam sebuah penelitian. Tanpa mengetahui teknik pengumpulan data, maka penelitian tidak akan mendapatkan data yang memenuhi standar data yang ditetapkan (Sugiyono,2010). Teknik pengumpulan data pada penelitian ini dilakukan dengan cara:

a. Observasi

Observasi adalah melihat secara langsung, mendengar, dan mengamati obyek penelitian.Pelaksanaan teknik dari observasi adalah mengamati obyek secara langsung sehingga memperoleh gambaran nyata dan obyektif.

b. Wawancara

Wawancara merupakan percakapan antara dua orang atau lebih dan berlangsung antar narasumber dan pewawancara. Wawancara pada penelitian ini dilakukan kepada tenaga kerja, yaitu mandor/kepala tukang, tukang, dan buruh bangunan/laden tukang pada kegiatan Pembangunan Fisik Gedung dan Bangunan Rumah Sakit Umum Daerah (RSUD) Kota Palangka Raya Tahap II.

c. Kuesioner

Kuesioner berupa pertanyaan/pernyataan yang diberikan kepada responden seperti mandor/kepala tukang, tukang, dan buruh bangunan/laden tukang pada kegiatan Pembangunan Fisik Gedung dan Bangunan Rumah Sakit Umum Daerah (RSUD) Kota Palangka Raya Tahap II.

d. Dokumentasi

Dokumentasi yaitu suatu bentuk pengabadian, arsip ataupun barang-barang peninggalan yang diabadikan. Dokumentasi digunakan untuk memperoleh data langsung dari tempat penelitian, seperti literatur bukubuku yang relevan, majalah, laporan kegiatan, catatan harian, notulen rapat, dan beberapa dokumen yang berkaitan dengan penelitian.

\section{Jenis Data}

Jenis data dalam penelitian ini terdiri dari dua jenis, yaitu:

a. Data Primer

Data primer adalah data yang diperoleh secara langsung dari responden/obyek penelitian.

b. Data Sekunder

Data sekunder adalah data yang diperoleh dari studi literatur, baik dari tulisan, referensi yang relevan, jurnal, buku artikel maupun sumbersumber lain yang menunjang penelitian.

\section{Populasi dan Sampel Penelitian}

Menurut Sugiyono (2010), populasi adalah wilayah generalisasi yang terdiri atas obyek/subjek yang mempunyai kualitas dan karakteristik tertentu yang ditetapkan oleh peneliti untuk dipelajari dan kemudian ditarik kesimpulannya. Berdasarkan studi pendahuluan pada bulan April 2017, populasi dalam penelitian ini adalah semua tenaga kerja (kepala tukang, tukang dan laden tukang) pada Kegiatan Pembangunan Fisik Gedung dan Bangunan Rumah Sakit Umum Daerah (RSUD) Kota Palangka Raya Tahap II yang berjumlah 36 orang.

Menurut Sugiyono (2010), sampel adalah sebagian dari jumlah dan karakteristik yang dimiliki oleh populasi tersebut. Teknik pemilihan sampel yang digunakan dalam penelitian ini adalah non random sampling dengan teknik sampling jenuh atau total sampling karena jumlah populasi yang relatif kecil.

Dalam penelitian ini beberapa faktor dikendalikan dengan memilih sampel (responden) penelitian berdasarkan kriteria yang ditentukan yaitu:

a. Responden adalah kepala tukang, tukang dan laden tukang.

b. Pendidikan responden minimal telah tamat SMP/Sederajat.

c. Usia responden adalah 20-50 tahun, karena merupakan usia produktif dan sigap dalam menerima suatu aktivitas. 
d. Memiliki pengalaman kerja minimal selama 2 tahun dalam pekerjaan konstruksi gedung. Menurut Sugiyono (2010), besarnya jumlah sampel yang layak dan dapat mewakili jumlah populasi dalam sebuah penelitian adalah antara 30 sampai dengan 500. Adapun sampel yang diteliti dalam penelitian ini adalah sebanyak 33 sampel (33 orang responden) yang dipilih berdasarkan kriteria yang sudah ditentukan.

\section{ANALISIS DATA}

\section{Gambaran Umum}

Obyek penelitian untuk survei dengan menggunakan kuesioner dan studi kasus mengenai faktor-faktor yang mempengaruhi perilaku tenaga kerja dalam penggunaan alat pelindung diri di proyek konstruksi pada Kegiatan Pembangunan Fisik Gedung dan Bangunan Rumah Sakit Umum Daerah (RSUD) Kota Palangka Raya Tahap II adalah para tenaga kerja konstruksi yang telah memenuhi kriteria yang telah ditentukan.

\section{Profil Responden}

Ada 33 responden yang memenuhi kriteria untuk diproses lebih lanjut. Data profil responden yang mewakili dan terlibat pada penelitian ini dapat ditunjukan pada Tabel 1.

\begin{tabular}{|c|c|c|c|c|c|}
\hline No & Nama & Usia & $\begin{array}{c}\text { Pend. } \\
\text { Terakhir }\end{array}$ & Pekerjaan & $\begin{array}{l}\text { Lama } \\
\text { Kerja }\end{array}$ \\
\hline 1 & Aap & 35 & SMA & Tukang & 9 tahun \\
\hline 2 & Abdul Hamid & 25 & SMA & Laden & 5 tahun \\
\hline 3 & Ahmad Taufik & 25 & SMA & Laden & 5 tahun \\
\hline 4 & Anam & 31 & SMA & Tukang & 10 tahun \\
\hline 5 & Andi & 21 & SMP & Laden & 3 tahun \\
\hline 6 & Arkani & 27 & SMP & Tukang & 8 tahun \\
\hline 7 & Bambang & 30 & SMA & Tukang & 10 tahun \\
\hline 8 & Barun Ulum & 40 & SMA & Tukang & 15 tahun \\
\hline 9 & Buamin & 50 & SMP & Laden & 26 tahum \\
\hline 10 & Budi & 30 & SMA & Kepala Tukang & 10 tahun \\
\hline 11 & Dul Hadi & 30 & SMP & Tukang & 10 tahun \\
\hline 12 & DwiPumama Sandi & 30 & SMA & Tukang & 10 tahum \\
\hline 13 & Hasan & 25 & SMP & Laden & 5 tahun \\
\hline 14 & Husin & 40 & SMP & Tukang & 15 tahun \\
\hline 15 & Hoirul & 40 & SMP & Laden & 15 tahun \\
\hline 16 & Imam & 30 & SMP & Tukang & 11 tahun \\
\hline 17 & Jumani & 30 & SMA & Tukang & 8 tahun \\
\hline 18 & Mang Marto & 36 & SMA & Tukang & 15 tahun \\
\hline 19 & Muhammad Saleh & 40 & SMP & Tukang & 15 tahun \\
\hline 20 & Niser & 30 & SMA & Tukang & 8 tahun \\
\hline 21 & Nur Hasan & 40 & SMP & Tukang & 12 tahun \\
\hline 22 & Nur Kholis & 30 & SMP & Tukang & 10 tahun \\
\hline 23 & Rahman & 30 & SMP & Tukang & 10 tahum \\
\hline 24 & Riki Diantoro & 25 & SMK & Laden & 3 tahun \\
\hline 25 & Sakri & 50 & SMP & Tukang & 15 tahun \\
\hline 26 & Subandi & 40 & SMA & Kepala Tukang & 10 tahun \\
\hline 27 & Supar & 40 & SMP & Tukang & 15 tahun \\
\hline 28 & Suwono & 50 & SMP & Tukang & 20 tahum \\
\hline 29 & Syamsul Hadi & 30 & SMP & Laden & 10 tahun \\
\hline 30 & Tohed Cahyono & 30 & SMA & Tukang & 10 tahun \\
\hline 31 & Upik & 25 & SMA & Laden & 3 tahun \\
\hline 32 & Yono & 32 & SMP & Tukang & 10 tahun \\
\hline 33 & Wahyu & 24 & SMP & Laden & 5 tahun \\
\hline
\end{tabular}

\section{Uji Validitas dan Reliabilitas Instrumen}

Uji validitas digunakan untuk mengukur valid tidaknya suatu instrumen. Suatu instrumen dikatakan valid jika item-item pertanyaan mampu mengungkapkan sesuatu yang hendak diukur oleh kuesioner tersebut.Instrumen valid apabila koefisien korelasi (pearson correlation) adalah positif, dengan $t_{\text {hitung }}>t_{\text {tabel }}$ dengan taraf signifikan $(\alpha)$ sebesar 0,05 .

Untuk menguji validitas alat ukur, terlebih dahulu dicari harga korelasi antara bagianbagian dari alat ukur secara keseluruhan dengan cara mengkorelasikan setiap butir alat ukur dengan skor total yang merupakan jumlah tiap skor butir, dengan menggunakan rumus Pearson Product Moment sebagai berikut :

$\mathbf{r}_{\text {hitung }} \frac{\mathbf{n}\left(\sum \mathbf{x y}\right)-\left(\sum \mathbf{x}\right)\left(\sum \mathbf{y}\right)}{\sqrt{\left(\mathbf{n} \cdot \sum \mathbf{x}^{2}-\left(\sum \mathbf{x}\right)^{2}\right) \cdot\left(\mathbf{n} \cdot \overline{\left.\left.\mathbf{y}^{2}-\left(\sum \mathbf{y}\right)^{2}\right)\right)}\right.}}$

Keterangan :

$\mathrm{r}_{\text {hitung }}=$ Koefisien korelasi

$\sum \mathrm{x}=$ Jumlah skor item

$\sum \mathrm{y}=$ Jumlah skor total

$\mathrm{n} \quad=$ Banyaknya responden

Tabel 2. Hasi Pengujian Validitas Instrumen

\begin{tabular}{|c|c|c|c|c|c|}
\hline Kode & Faktor-faktor & $\begin{array}{c}\text { Koefisien } \\
\text { Korelasi } \\
\left(\mathrm{r}_{\text {hirng }}\right)\end{array}$ & $\begin{array}{l}\text { Harga } \\
\left(t_{\text {bitumg }}\right)\end{array}$ & $\begin{array}{c}\text { Harga } \\
\left(t_{\text {tabet }}\right)\end{array}$ & Keterangan \\
\hline $\mathrm{A}$ & \multicolumn{5}{|c|}{ Faktor Predisposisi } \\
\hline A.1 & Pengetahuan & 0.54012 & 3.57334 & 1,69522 & Valid \\
\hline A.2 & Sikap & 0.52265 & 3.41332 & 1,69522 & Valid \\
\hline A.3 & Kenyamanan & 0.70548 & 5.54225 & 1,69522 & Valid \\
\hline B & \multicolumn{5}{|c|}{ Faktor Pemunghin } \\
\hline B.1 & $\begin{array}{l}\text { Ketersediaan } \\
\text { Fasilitas }\end{array}$ & 0.74133 & 6.14996 & 1,69522 & Valid \\
\hline B.2 & Pelatihan & 0.62800 & 4.49310 & 1,69522 & Valid \\
\hline $\mathrm{C}$ & \multicolumn{5}{|l|}{ FaktorPenguat } \\
\hline C.1 & Pengawasan & 0.54782 & 3.64592 & 1,69522 & Valid \\
\hline $\mathrm{C} .2$ & Hukuman & 0.43497 & 2.68954 & 1,69522 & Valid \\
\hline C.3 & Penghargaan & 0.47564 & 3.01064 & 1,69522 & Valid \\
\hline C.4 & Motivasi & 0.52885 & 3.46935 & 1,69522 & Valid \\
\hline C.5 & Komunikasi & 0.66585 & 4.96897 & 1,69522 & Valid \\
\hline $\mathrm{D}$ & \multicolumn{5}{|l|}{ FaktorIndividu } \\
\hline D.1 & Pendidikan & 0.56770 & 3.83952 & 1,69522 & Valid \\
\hline D.2 & Umur & 0.64960 & 4.75722 & 1,69522 & Valid \\
\hline D.3 & Masakerja & 0.51438 & 3.33967 & 1,69522 & Valid \\
\hline
\end{tabular}

Uji reliabilitas digunakan untuk menguji apakah instrumen dapat dipercaya atau mampu menghasilkan ukuran yang konsisten walaupun digunakan untuk mengukur berkali-kali. Untuk mengetahui reliabilitas alat pengumpulan data, dapat dilakukan pegujian dengan mengunakan rumus Spearman Brown sebagai berikut:

Keterangan :

$$
\mathbf{r}_{11}=\frac{2 \mathbf{r}_{\mathbf{b}}}{1+\mathbf{r}_{\mathbf{b}}}
$$

$\mathrm{r}_{11}=$ Koefisien reliabilitas

$\mathrm{r}_{\mathrm{b}} \quad=$ Koefisien Product Moment 


\begin{tabular}{|c|c|c|c|c|c|}
\hline Kode & Faktor-faktor & $\begin{array}{c}\text { Koefisien } \\
\text { Korelasi } \\
\text { (rb) }\end{array}$ & $\underset{\left(\mathrm{r}_{11}\right)}{\mathrm{Harga}}$ & $\begin{array}{c}\text { Harga } \\
\left(\mathrm{r}_{\text {tabe }}\right)\end{array}$ & Keterangan \\
\hline A & \multicolumn{5}{|c|}{ Faktor Predisposisi } \\
\hline A. 1 & Pengetahuan & 0.54012 & 0.70140 & 0,34400 & Reliabel \\
\hline A. 2 & \begin{tabular}{|l} 
Sikap \\
\end{tabular} & 0.52265 & 0.68650 & 0,34400 & Reliabel \\
\hline A.3 & Kenyamanan & 0.70548 & 0.82731 & 0,34400 & Reliabel \\
\hline B & \multicolumn{5}{|c|}{ Faktor Pemungkin } \\
\hline B.1 & $\begin{array}{l}\text { Ketersediaan } \\
\text { Fasilitas } \\
\end{array}$ & 0.74133 & 0.851449 & 0,34400 & Reliabel \\
\hline B. 2 & Pelatihan & 0.62800 & 0.771501 & 0,34400 & Reliabel \\
\hline $\mathrm{C}$ & \multicolumn{5}{|l|}{ Faktor Penguat } \\
\hline C.1 & Pengawasan & 0.54782 & 0.70786 & 0,34400 & Reliabel \\
\hline $\mathrm{C} .2$ & Hukuman & 0.43497 & 0.60624 & 0,34400 & Reliabel \\
\hline C. 3 & Penghargaan & 0.47564 & 0.64466 & 0,34400 & Reliabel \\
\hline C. 4 & Motivasi & 0.52885 & 0.69182 & 0,34400 & Reliabel \\
\hline C.5 & Komunikasi & 0.66585 & 0.79941 & 0,34400 & Reliabel \\
\hline D & \multicolumn{5}{|l|}{ FaktorIndividu } \\
\hline D.1 & \begin{tabular}{|l|} 
Pendidikan \\
\end{tabular} & 0.56770 & 0.724246 & 0,34400 & Reliabel \\
\hline D.2 & Umur & 0.64960 & 0.787583 & 0,34400 & Reliabel \\
\hline D. 3 & Masakerja & 0.51438 & 0.679331 & 0,34400 & Reliabel \\
\hline
\end{tabular}

Berdasarkan hasil pengujian validitas dan reliabilitas memperlihatkan bahwa faktor predisposisi, faktor pemungkin, faktor penguat dan faktor individu memenuhi syarat yang ditentukan. Sehingga dapat disimpulkan bahwa instrumen yang digunakan pada penelitian ini adalah valid dan reliabel.

\section{Analisis Deskriptif}

Analisis deskriptif dilakukan untuk menjawab tujuan penelitian. Analisis dilakukan secara berurutan tiap-tiap faktor yang mempengaruhi beserta sub faktornya. Analisis yang dipakai adalah analisis mean dan standar deviasi. Selanjutnya dari kedua analisis ini, ditentukan faktor-faktor mana saja yang yang mempengaruhi perilaku tenaga kerja dalam penggunaan alat pelindung diri di proyek konstruksi pada Kegiatan Pembangunan Fisik Gedung dan Bangunan Rumah Sakit Umum Daerah (RSUD) Kota Palangka Raya Tahap II dan faktor apa yang dominan.

Mean adalah sebuah rata-rata dari data yang diperoleh berupa angka. Jawaban responden pada kuesioner mengenai faktor-faktor yang mempengaruhi perilaku tenaga kerja dalam penggunaan alat pelindung diri di proyek konstruksi pada Kegiatan Pembangunan Fisik Gedung dan Bangunan Rumah Sakit Umum Daerah (RSUD) Kota Palangka Raya Tahap II, untuk masing-masing faktor dijumlahkan (berdasarkan nilai skalanya), kemudian dibagi dengan jumlah responden.

Persamaan mean yang umum dipakai yaitu:

$$
\mathbf{X}=\frac{\sum \overline{\mathrm{X}}}{\mathrm{N}}
$$

Keterangan:

$\overline{\mathrm{X}} \quad=$ Mean atau nilai rata-rata

$\sum \mathrm{X}=$ Total frekuensi

$\mathrm{N} \quad=$ Banyaknya data

Contoh perhitungan nilai mean untuk item No.

1 Pertanyaan A :

$\bar{X}=\frac{\sum X}{N}=\frac{144}{33}=4,36$

Standar deviasi adalah ukuran sebaran statistik yang paling lazim. Singkatnya, standar deviasi mengukur bagaimana nilai-nilai data tersebar. Bisa juga didefinisikan sebagai rata-rata jarak penyimpangan titik-titik data diukur dari nilai rata-rata data tersebut.

Persamaan standar deviasi yaitu :

$$
\mathrm{SD}=\sqrt{\frac{1}{\mathrm{~N}} \sum(\mathrm{X}-\mathrm{X})^{2}}
$$

Keterangan :

$\mathrm{SD} \quad=$ Standar deviasi

$\sum(\mathrm{X}-\mathrm{X})^{2}=$ Total kuadrat nilai data dikurangi rata-rata

$\mathrm{N} \quad=$ Banyaknya data

Contoh perhitungan nilai standar deviasi untuk item No. 1 Pertanyaan A :

$\mathrm{SD}=\sqrt{\frac{1}{\mathrm{~N}} \sum(\overline{\mathrm{X}-\mathrm{X}})^{2}}=\sqrt{\frac{1}{33} \times 34,06}=1,02$

Analisis deskriptif faktor predisposisi dapat dilihat pada Tabel 4. Untuk analisis deskriptif faktor pemungkin dapat dilihat pada Tabel 5 . Sedangkan analisis deskriptif faktor penguat dapat dilihat pada Tabel 6 dan untuk analisis deskriptif faktor individu dapat dilihat pada Tabel 7.

Tabel 4. Analisis Deskriptif Faktor-faktor Predisposisi

\begin{tabular}{|c|l|c|c|c|}
\hline Kode & \multicolumn{1}{|c|}{ Faktor-Faktor } & Mean & $\begin{array}{c}\text { Standar } \\
\text { Deviasi }\end{array}$ & Rank \\
\hline A & Faktor Predisposisi & 4,35 & & \\
\hline A.1 & Pengetahuan & 4.36 & 0.73 & 2 \\
\hline A.2 & Sikap & 4.48 & 0.82 & 1 \\
\hline A.3 & Kenyamanan & 4.21 & 1.04 & 3 \\
\hline
\end{tabular}

Sumber: Hasil Analisis

Nilai mean pada Tabel 4. dapat dibuat diagram seperti pada Gambar 1 di bawah ini. 


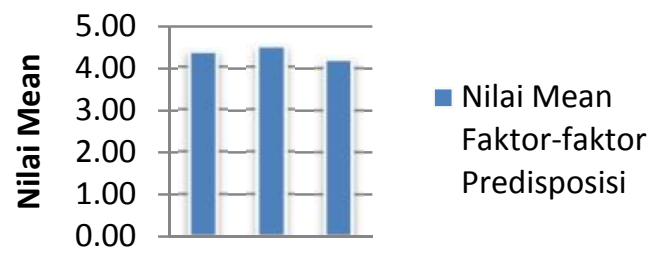

A.1 A.2 A.3

Gambar 1 Diagram Nilai Mean Faktor-faktor Predisposisi

Dari Tabel 4. dan Gambar 1 dapat diketahui bahwa:

- Faktor predisposisi dengan nilai mean 4,35 dipengaruhi oleh sub faktor dominan yaitu sikap (A.2) dengan nilai mean 4,48.

- Sub faktor peringkat pertama (dominan) adalah sikap (A.2) dengan nilai mean sebesar 4,48 dan standar deviasi 0,82.

- Sub faktor peringkat kedua adalah pengetahuan (A.1) dengan nilai mean sebesar 4,36 dan standar deviasi 0,73.

- Sub faktor peringkat ketiga adalah kenyamanan (A.3) dengan nilai mean sebesar 4,21 dan standar deviasi 1,04.

Analisis deskriptif faktor pemungkin yang mempengaruhi perilaku tenaga kerja dalam penggunaan alat pelindung diri di proyek konstruksi pada Kegiatan Pembangunan Fisik Gedung dan Bangunan Rumah Sakit Umum Daerah (RSUD) Kota Palangka Raya Tahap II dapat dilihat pada Tabel 5 di bawah ini.

Tabel 5. Analisis Deskriptif Faktor Pemungkin

\begin{tabular}{|c|l|c|c|c|}
\hline Kode & \multicolumn{1}{|c|}{ Faktor-Faktor } & Mean & $\begin{array}{c}\text { Standar } \\
\text { Deviasi }\end{array}$ & Rank \\
\hline B & Faktor Pemungkin & 4,29 & & \\
\hline B.1 & $\begin{array}{l}\text { Ketersediaan } \\
\text { Fasilitas }\end{array}$ & 4.24 & 1.02 & 2 \\
\hline B.2 & Pelatihan & 4.33 & 0.88 & 1 \\
\hline
\end{tabular}

Sumber: Hasil Analisis

Nilai mean pada Tabel 5 dapat dibuat diagram seperti pada Gambar 2 di bawah ini.

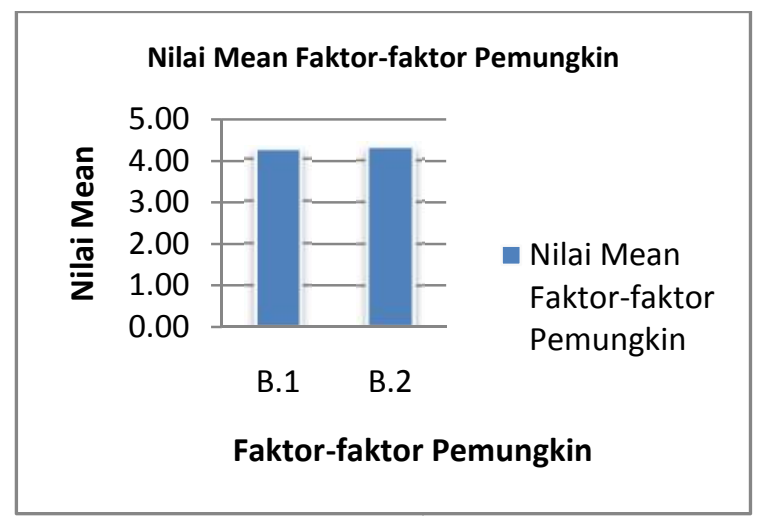

Gambar 2 Diagram Nilai Mean Faktor-faktor Pemungkin

Dari Tabel 5 dan Gambar 2 dapat diketahui bahwa:

- Faktor pemungkin dengan nilai mean 4,29 dipengaruhi oleh sub faktor dominan yaitu pelatihan (B.2) dengan nilai mean 4,33.

- Sub faktor peringkat pertama (dominan) adalah pelatihan (B.2) dengan nilai mean sebesar 4,33 dan standar deviasi 0,88.

- Sub faktor peringkat kedua adalah ketersediaan fasilitas (B.1) dengan nilai mean sebesar 4,24 dan standar deviasi 1,02.

Analisis deskriptif faktor penguat yang mempengaruhi perilaku tenaga kerja dalam penggunaan alat pelindung diri di proyek konstruksi pada Kegiatan Pembangunan Fisik Gedung dan Bangunan Rumah Sakit Umum Daerah (RSUD) Kota Palangka Raya Tahap II dapat dilihat pada Tabel 6 di bawah ini.

Tabel 6. Analisis Deskriptif Faktor-faktor Penguat

\begin{tabular}{|c|l|c|c|c|}
\hline Kode & Faktor-Faktor & Mean & $\begin{array}{c}\text { Standar } \\
\text { Deviasi }\end{array}$ & Rank \\
\hline C & Faktor Penguat & 4,19 & & \\
\hline C.1 & Pengawasan & 4.67 & 0.59 & 1 \\
\hline C.2 & Hukuman & 4.52 & 0.70 & 2 \\
\hline C.3 & Penghargaan & 4.18 & 1.09 & 3 \\
\hline C.4 & Motivasi & 3.85 & 1.08 & 4 \\
\hline C.5 & Komunikasi & 3.73 & 1.16 & 5 \\
\hline
\end{tabular}

Sumber: Hasil Analisis

Nilai mean pada Tabel 6 dapat dibuat diagram seperti pada Gambar 3 di bawah ini. 


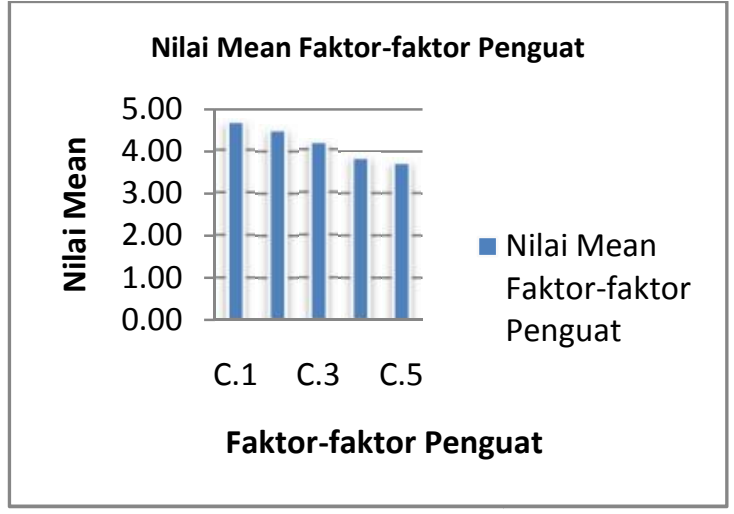

Gambar 3 Diagram Nilai Mean Faktor-faktor Penguat

Dari Tabel 6 dan Gambar 3 dapat diketahui bahwa:

- Faktor penguat dengan nilai mean 4,19 dipengaruhi oleh sub faktor dominan yaitu pengawasan (C.1) dengan nilai mean 4,67.

- Sub faktor peringkat pertama (dominan) adalah pengawasan (C.1) dengan nilai mean sebesar 4,67 dan standar deviasi 0,59.

- Sub faktor peringkat kedua adalah hukuman (C.2) dengan nilai mean sebesar 4,52 dan standar deviasi 0,70 .

- Sub faktor peringkat ketiga adalah penghargaan (C.3) dengan nilai mean sebesar 4,18 dan standar deviasi 1,09.

- Sub faktor peringkat empat adalah motivasi (C.4) dengan nilai mean sebesar 3,85 dan standar deviasi 1,08.

- Sub faktor peringkat kelima adalah komunikasi (C.5) dengan nilai mean sebesar 3,73 dan standar deviasi 1,16 .

Analisis deskriptif faktor individu yang mempengaruhi perilaku tenaga kerja dalam penggunaan alat pelindung diri di proyek konstruksi pada Kegiatan Pembangunan Fisik Gedung dan Bangunan Rumah Sakit Umum Daerah (RSUD) Kota Palangka Raya Tahap II dapat dilihat pada Tabel 7 di bawah ini.

Tabel 7 Analisis Deskriptif Faktor-faktor Individu

\begin{tabular}{|c|l|c|c|c|}
\hline Kode & \multicolumn{1}{|c|}{ Faktor-Faktor } & Mean & $\begin{array}{c}\text { Standar } \\
\text { Deviasi }\end{array}$ & Rank \\
\hline D & Faktor Individu & 3,73 & & \\
\hline D.1 & Pendidikan & 3.94 & 1.15 & 1 \\
\hline D.2 & Umur & 3.39 & 1.20 & 3 \\
\hline D.3 & Masa kerja & 3.85 & 1.02 & 2 \\
\hline
\end{tabular}

Sumber: Hasil Analisis
Nilai mean pada Tabel 7 dapat dibuat diagram seperti pada Gambar 4 di bawah ini.

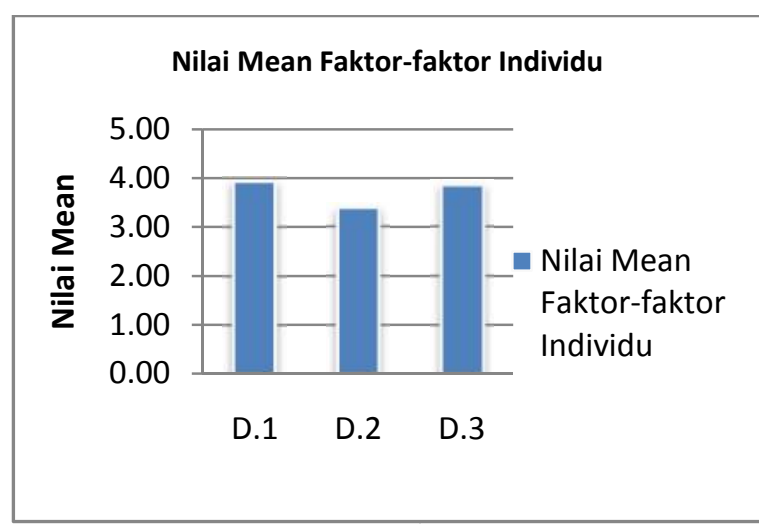

Gambar 4.Diagram Nilai Mean Faktor-faktor Individu

Dari Tabel 7 dan Gambar 4 dapat diketahui bahwa:

- Faktor individu dengan nilai mean 3,73 di pengaruhi oleh sub faktor dominan yaitu pendidikan (D.1) dengan nilai mean 3,94.

- Sub faktor peringkat pertama (dominan) adalah pendidikan (D.1) dengan nilai mean sebesar 3,94 dan standar deviasi 1,15.

- Sub faktor peringkat kedua adalah masa kerja (D.3) dengan nilai mean sebesar 3,85 dan standar deviasi 1,02.

- Sub faktor peringkat ketiga adalah umur (D.2) dengan nilai mean sebesar 3,39 dan standar deviasi 1,20.

\section{Rangking Faktor Pengaruh}

Peringkat diurutkan dari nilai mean yang paling besar. Apabila ada kesamaan nilai mean maka dipilih nilai standar deviasi yang lebih kecil dan apabila nilai mean dan standar deviasi sama maka peringkat dirata-ratakan. Untuk rangking peringkat tiap-tiap sub faktor yang mempengaruhi perilaku tenaga kerja dalam penggunaan alat pelindung diri di proyek konstruksi pada Kegiatan Pembangunan Fisik Gedung dan Bangunan Rumah Sakit Umum Daerah (RSUD) Kota Palangka Raya Tahap II dapat dilihat pada Tabel 8 dibawah ini. 
Tabel 8.Rangking Keseluruhan Mean Sub faktor

\begin{tabular}{|c|l|c|c|c|}
\hline Kode & \multicolumn{1}{|c|}{ Sub Faktor } & Mean & $\begin{array}{c}\text { Standar } \\
\text { Deviasi }\end{array}$ & Rank \\
\hline C.1 & Pengawasan & 4.67 & 0.59 & 1 \\
\hline C.2 & Hukuman & 4.52 & 0.70 & 2 \\
\hline A.2 & Sikap & 4.48 & 0.82 & 3 \\
\hline A.1 & Pengetahuan & 4.36 & 0.73 & 4 \\
\hline B.2 & Pelatihan & 4.33 & 0.88 & 5 \\
\hline B.1 & Ketersediaan Fasilitas & 4.24 & 1.02 & 6 \\
\hline A.3 & Kenyamanan & 4.21 & 1.04 & 7 \\
\hline C. 3 & Penghargaan & 4.18 & 1.09 & 8 \\
\hline D.1 & Pendidikan & 3.94 & 1.15 & 9 \\
\hline D. 3 & Masa kerja & 3.85 & 1.02 & 10 \\
\hline C.4 & Motivasi & 3.85 & 1.08 & 11 \\
\hline C.5 & Komunikasi & 3.73 & 1.16 & 12 \\
\hline D. 2 & Umur & 3.39 & 1.20 & 13 \\
\hline
\end{tabular}

Sumber: Hasil analisis

Berdasarkan Tabel 8 dapat diketahui bahwa 4 (empat) sub faktor teratas dari tiap keseluruhan sub faktor yang mempengaruhi perilaku tenaga kerja dalam penggunaan alat pelindung diri di proyek konstruksi pada Kegiatan Pembangunan Fisik Gedung dan Bangunan Rumah Sakit Umum Daerah (RSUD) Kota Palangka Raya Tahap II yaitu peringkat pertama adalah faktor pengawasan (C.1) dengan nilai mean sebesar 4,67 dan standar deviasi 0,59. Peringkat kedua diduduki oleh faktor hukuman (C.2) dengan nilai mean sebesar 4,52 dan standar deviasi 0,70. Peringkat ketiga diduduki oleh faktor sikap (A.2) dengan nilai mean sebesar 4,48 dan standar deviasi 0,82. Sedangkan untuk peringkat keempat diduduki oleh faktor pengetahuan (A.1) dengan nilai mean sebesar 4,36 dan standar deviasi 0,73 .

Tabel 9. Rangking Keseluruhan Mean Faktor

\begin{tabular}{|c|c|c|c|c|c|c|}
\hline \multirow[b]{2}{*}{ Kode } & \multirow[b]{2}{*}{ Faktor-Faktor } & \multicolumn{3}{|c|}{ Sub Faktor } & \multicolumn{2}{|c|}{ Faktor } \\
\hline & & Mean & $\begin{array}{c}\text { Standar } \\
\text { Deviasi }\end{array}$ & Rank & Mean & Rank \\
\hline $\mathbf{A}$ & Faktor Predispos & & & & \multirow{4}{*}{4,35} & \multirow{4}{*}{1} \\
\hline A 1 & Pengetahilan & 4.36 & 0.73 & 4 & & \\
\hline A.2 & Sikap & 4.48 & 0.82 & 3 & & \\
\hline A.3 & Kenyamanan & 4.21 & 1.04 & 7 & & \\
\hline B & \multicolumn{6}{|c|}{ Faktor Pemungkin } \\
\hline B.1 & $\begin{array}{l}\text { Ketersediaan } \\
\text { Fasilitas }\end{array}$ & 4.24 & 1.02 & 6 & \multirow[t]{2}{*}{4,29} & \multirow[t]{2}{*}{2} \\
\hline 3.2 & Pclatihen & 4.33 & 0.88 & 5 & & \\
\hline $\mathrm{C}$ & \multicolumn{6}{|l|}{ Faktor Penguat } \\
\hline C.1 & Pengawasan & 4.67 & 0.59 & 1 & \multirow{5}{*}{4.19} & \multirow{5}{*}{3} \\
\hline C.2 & Hukuman & 4.52 & 0.70 & 2 & & \\
\hline C.3 & Penghargaan & 4.18 & 1.09 & 8 & & \\
\hline C.1 & Motivasi & 3.85 & 1.08 & 11 & & \\
\hline C.5 & Komunikasi & 3.73 & 1.16 & 12 & & \\
\hline $\mathrm{D}$ & \multicolumn{6}{|l|}{ Faktor Individu } \\
\hline D.1 & Pendidikan & 3.94 & 1.15 & 9 & \multirow{3}{*}{3.73} & \multirow{3}{*}{4} \\
\hline D.2 & Umur & 3.39 & 1.20 & 13 & & \\
\hline D. 3 & Masa kerja & 3.85 & 1.02 & 10 & & \\
\hline
\end{tabular}

Sumber: Hasil analisis
Berdasarkan Tabel 9 dapat diketahui bahwa peringkat pertama dari keseluruhan faktorfaktor yang mempengaruhi perilaku tenaga kerja dalam penggunaan alat pelindung diri di proyek konstruksi pada Kegiatan Pembangunan Fisik Gedung dan Bangunan Rumah Sakit Umum Daerah (RSUD) Kota Palangka Raya Tahap II adalah faktor predisposisi (A) dengan nilai mean sebesar 4,35. Peringkat kedua diduduki oleh faktor pemungkin (B) dengan nilai mean sebesar 4,29. Peringkat ketiga diduduki oleh faktor penguat (C) dengan nilai mean sebesar 4,19. Sedangkan untuk peringkat keempat diduduki oleh faktor individu (D) dengan nilai mean sebesar 3,73.

Tabel 9 menyajikan nilai rata-rata dari mean dan standar deviasi setiap faktor. Nilai mean berkisar antara 3,37 - 4,35 menunjukan bahwa faktor tersebut lebih dari cukup pengaruhnya ( $\geq 3$ ) dan nilai-nilai mean inilah yang dipakai untuk menentukan faktor-faktor mana yang mempengaruhi perilaku tenaga kerja dalam penggunaan alat pelindung diri di proyek konstruksi pada Kegiatan Pembangunan Fisik Gedung dan Bangunan Rumah Sakit Umum Daerah (RSUD) Kota Palangka Raya Tahap II. Sedangkan untuk nilai mean diatas 4 (empat) dipilih sebagai faktor yang paling dominan.

Sehingga faktor-faktor yang mempengaruhi perilaku tenaga kerja dalam penggunaan alat pelindung diri di proyek konstruksi pada Kegiatan Pembangunan Fisik Gedung dan Bangunan Rumah Sakit Umum Daerah (RSUD) Kota Palangka Raya Tahap II adalah 1) faktor predisposisi, 2) faktor pemungkin, 3) faktor penguat, dan 4) faktor individu.

Sedangkan untuk faktor dominan yang mempengaruhi perilaku tenaga kerja dalam penggunaan alat pelindung diri di proyek konstruksi pada Kegiatan Pembangunan Fisik Gedung dan Bangunan Rumah Sakit Umum Daerah (RSUD) Kota Palangka Raya Tahap II adalah 1) faktor predisposisi, 2) faktor pemungkin, 3) faktor penguat.

\section{KESIMPULAN}

Kesimpulan penelitian ini adalah:

1. Faktor-faktor yang mempengaruhi perilaku tenaga kerja dalam penggunaan alat pelindung diri di proyek konstruksi pada Kegiatan Pembangunan Fisik Gedung dan Bangunan Rumah Sakit Umum Daerah (RSUD) Kota Palangka Raya Tahap II, yaitu: 
a. Faktor predisposisi : pengetahuan, sikap, dan kenyamanan.

b. Faktor pemungkin : ketersediaan fasilitas dan pelatihan.

c. Faktor pendorong: pengawasan, hukuman, penghargaan, motivasi dan komunikasi.

d. Faktor individu : pendidikan, umur dan masa kerja.

2. Faktor dominan yang mempengaruhi perilaku tenaga kerja dalam penggunaan alat pelindung diri di proyek konstruksi pada Kegiatan Pembangunan Fisik Gedung dan Bangunan Rumah Sakit Umum Daerah (RSUD) Kota Palangka Raya Tahap II, yaitu:

a. Faktor predisposisi (A) dengan nilai mean sebesar 4,35.

b. Faktor pemungkin (B) dengan nilai mean sebesar 4,29.

c. Faktor penguat (C) dengan nilai mean sebesar 4,19.

\section{SARAN}

Berdasarkan kesimpulan di atas, maka dapat diambil beberapa saran. Saran-saran tersebut yaitu:

1. Tenaga kerja perlu lebih meningkatkan pengetahuan dan kesadaran akan pentingnya penggunaan alat pelindung diri, serta pekerja juga harus memiliki sikap dan perilaku yang baik dalam penggunaan alat pelindung diri selama mereka bekerja.

2. Kontraktor diharapkan melakukan pengawasan, motivasi dan komunikasi yang baik terhadap tenaga kerjanya agar selalu menggunakan alat pelindung diri disaat mereka bekerja. Serta mempersiapkan semua fasilitas kelengkapan keselamatan dan kesehatan kerja (alat pelindung diri) yang nyaman dan sesuai dengan standar yang sudah ditentukan.

3. Pemerintah perlu melakukan pelatihan dan pengawasan berkala agar tenaga kerja lebih mengerti pentingnya penggunaan alat pelindung diri.

4. Diperlukan penelitian lebih lanjut mengenai faktor-faktor yang mempengaruhi perilaku tenaga kerja dalam penggunaan alat pelindung diri di proyek konstruksi karena bukan tidak mungkin masih ada faktorfaktor lain yang belum masuk di dalam penelitian ini.

\section{DAFTAR PUSTAKA}

Bandura, A., and Walters, R. H., 1963, Social learning and personality development, New York.

Ervianto,W. I., 2005. Manajemen Proyek Konstruksi, Cetakan Ketiga, Penerbit ANSI, Yogyakarta.

Hand, Gerard, 2013, Ancaman Kecelakaan Kerja di Indonesia Masih Tinggi, Suara Pembaruan, Jakarta.

King, R.W., Hudson, R., 1985, Construction Hazard and Safety Handbook: Safety Butterworths, Inggris.

Notoadmodjo, Soekidjo, 2003, Pendidikan dan Perilaku Kesehatan Masyarakat, PT. Rineka Cipta, Jakarta.

Suma'mur.P.K., 1995, Higiene Perusahaan dan Kesehatan Kerja, PT. Gunung Agung, Jakarta.

2010, Higiene Perusahaan dan Kesehatan Kerja (Hiperkes), CV Sagung Seto, Jakarta. 
